\title{
The use of random amplified polymorphic DNA to evaluate the genetic variability of Ponkan mandarin (Citrus reticulata Blanco) accessions
}

\author{
Helvécio Della Coletta Filho, Marcos Antonio Machado, M. Luiza P.N. Targon and Jorgino Pompeu Jr.
}

\begin{abstract}
RAPD analysis of 19 Ponkan mandarin accessions was performed using 25 random primers. Of 112 amplification products selected, only 32 were polymorphic across five accessions. The absence of genetic variability among the other 14 accessions suggested that they were either clonal propagations with different local names, or that they had undetectable genetic variability, such as point mutations which cannot be detected by RAPD.
\end{abstract}

\section{INTRODUCTION}

Ponkan mandarins probably originated in southern China and Taiwan or possibly India. Because of their excellent qualities these mandarins were widely cultivated throughout the Orient, reaching Europe in 1805 and North America in 1892 (Tanaka, 1954). This mandarin group has several varieties that are especially suited to the tropical climate of the Orient (from the Philippines to Iraq), Brazil, and, to a lesser extent, Florida (Young, 1986).

Several types of mandarins are known in India and probably represent the nucellar clonal budlines of 'Ponkan' originally known as 'Nagpur Suntara' or 'Santra'. The Ponkan varieties 'Oneco' and 'Warnurco' in Florida originated from seeds from north western India. 'Ponkan' mandarins are also known by other names such as 'Emperor' (Australia), 'Empress' and 'South Africa' (South Africa), 'Batangas' (Philippines), 'Muscia' (Italy) and 'Coorg', 'Assam' or 'Butwall' (India).

Climatically, 'Ponkan' is one of the most tropical mandarins, with the fruits reaching maximum size and quality under tropical conditions, there being little competition from other mandarins (Hodgson, 1967). Brazil is one of the major producers of mandarins, with about $41 \%$ of the produce being the 'Ponkan' variety (Figueiredo, 1991), most of which is destined for the fresh fruit market. The genetic uniformity of Brazilian mandarin orchards makes them vulnerable to pathogen or insectcaused catastrophes. Additionally, these mandarins have a limited harvesting period and, once ripe, they do not last long on the tree. The economic importance of the 'Ponkan' mandarin variety has led to the establishment of living tree germplasm collections. Data on the distribution of genetic variability and the relationships among Ponkan varieties are necessary in order to avoid duplications, and to establish core collections representative of the genetic variability of the group in which agricultur- ally important genes may occur. Such information may help breeding programs and optimize the search for desirable characteristics.

Conventional breeding of citrus plants is traditionally slow and difficult, mainly because of the complex reproductive biology, involving polyploidy, high heterozygosity and single gene inheritance patterns in a few traits. Also, the prolonged juvenile period of seedlings in the field makes citrus breeding very lengthy. Recent technological advances have partially solved some of the limitations associated with classic citrus breeding. Molecular based markers have been used to construct linkage maps (Cai et al., 1994; Kijas et al., 1995), identify genotypes (Motohashi et al., 1992; Albanese et al., 1992), distinguish hybrids from nucellar seedlings (Bastianel et al., 1998), explore phylogenetic relationships (Luro et al., 1992; Herrero et al., 1996) and evaluate citrus germplasm collections (Machado et al., 1996; Coletta Filho et al., 1998). In the latter two studies, random amplified polymorphic DNA (RAPD) analysis of several commercial and non-commercial mandarin accessions showed that this approach provided a quick and reliable method for evaluating diversity and genetic relationships. In both studies, closely related accessions were separated, with genotypespecific RAPD markers being obtained in some cases.

Untill now, no attempts have been made to evaluate germplasm collections of Ponkan mandarins using RAPD molecular markers. We used this approach to study the genetic variability of a germplasm collection of Ponkan mandarins.

\section{MATERIAL AND METHODS}

Plant material

Nineteen Ponkan mandarin accessions belonging to the germplasm collections at the Centro de Citricultura 
Table I - Regional names and origins of Ponkan mandarin accessions analyzed using RAPDs.

\begin{tabular}{|cllcll|}
\hline Accession & Name & Origin & Accession & Name & Origin \\
\hline 1 & Muscia & Australia & 11 & Batangas & Phillipines \\
2 & Ponkan & China & 12 & Sylhat & $*$ \\
3 & Ponkan Tuxpan & Mexico & 13 & Mandalina & Corsega \\
4 & Loose Jacket & $*$ & 14 & Emperor & Australia \\
5 & Tangor & Brazil & 15 & Wildt & South Africa \\
6 & Hung Kat & China & 16 & South Africa & South Africa \\
7 & Warnurco & USA & 17 & Green Rind & South Africa \\
8 & Empress & South Africa & 18 & Rosehaugh Nartjee & South Africa \\
9 & Pan-American & Corsega & 19 & Oneco & USA \\
10 & Swaton & $*$ & & & \\
\hline
\end{tabular}

*Information not available.

Sylvio Moreira - IAC, Campinas, SP, Brazil, were investigated (Table I).

\section{DNA isolation}

Total DNA was isolated from $100 \mathrm{mg}$ of lyophilized leaves using the method of Murray and Thompson (1980) as modified by Machado et al. (1996). The quality and quantity of DNA were determined as described by Sambrook et al. (1989).

\section{Amplification reactions}

The DNA amplification reactions were performed using $1.3 \mu \mathrm{l}$ of $10 \mathrm{x}$ buffer $(100 \mathrm{mM}$ Tris-HCl, $\mathrm{pH} 8.3$, $500 \mathrm{mM} \mathrm{KCl}, 20 \mathrm{mM} \mathrm{MgCl}_{2}, 0.01 \%$ gelatin), $200 \mu \mathrm{M}$ each of dATP, dCTP, dTTP, dGTP (Gibco BRL), $15 \mathrm{ng}$ of 10 -base pair primers (Operon) or 8-mer primer (CaetanoAnollés et al., 1991), 10 ng of genomic DNA and 1.5 units of Taq polymerase (Promega). The final volume was completed to $12.3 \mu \mathrm{l}$ with ultrapure water. The reaction mixtures were overlaid with mineral oil and the amplification was performed in a Robocycler (Stratagene) programmed for 36 cycles of $1 \mathrm{~min}$ at $92^{\circ} \mathrm{C}, 1 \mathrm{~min}$ at $36^{\circ} \mathrm{C}$ and $2 \mathrm{~min}$ at $72^{\circ} \mathrm{C}$, using the fastest ramping time, with a final extension at $72^{\circ} \mathrm{C}$ for $10 \mathrm{~min}$, followed by cooling at $20^{\circ} \mathrm{C}$ until recovery of the sample. Aliquots of the amplification products were analyzed by electrophoresis in $1.4 \%$ agarose gels containing $0.5 \mathrm{ng}$ of ethidium bromide $/ \mathrm{ml}$. Molecular sizes of the amplifications products were estimated by a 1-kb DNA ladder (Gibco BRL). The gels were photographed using a UV-transilluminator with Polaroid film 667.

\section{Data analysis}

The amplifications obtained were compiled into a two-way matrix (accessions x markers) of the specific amplification products. Only reproducible and well-characterized RAPDs were used in this analysis (Grattapaglia and Sederoff, 1994). Cluster analysis was performed using the unweighted pair-group method arithmetic average (UPGMA), with the Jaccard coefficient calculated by the software NTSYS-PC version 1.7 (Rohlf, 1992).

\section{RESULTS AND DISCUSSION}

All of the primers produced amplifications (Table II). However, 10 of them revealed no polymorphism among the 19 Ponkan mandarin accessions. A total of 112 bands were scored, of which only 32 were polymorphic. The

Table II - The sequences of the primers used and the number of fragments produced.

\begin{tabular}{|c|c|c|c|}
\hline Primer & Sequence & $\begin{array}{l}\text { Total number } \\
\text { of fragments* }\end{array}$ & $\begin{array}{l}\text { Number of } \\
\text { polymorphic } \\
\text { fragments** }\end{array}$ \\
\hline P130 & CGCGGCCA & 5 & 1 \\
\hline OPA01 & CAGGCCCTTC & 2 & 1 \\
\hline OPA16 & AGCCAGCGAA & 3 & 0 \\
\hline OPA18 & AGGTGACCGT & 3 & 0 \\
\hline OPG10 & AGGGCCGTCT & 6 & 3 \\
\hline OPG13 & CTCTCCGCCA & 2 & 0 \\
\hline OPG14 & GGATGAGACC & 6 & 4 \\
\hline OPG19 & GTCAGGGCAA & 6 & 3 \\
\hline OPH04 & GGAAGTCGGC & 2 & 1 \\
\hline OPH05 & AGTCGTCCCC & 2 & 0 \\
\hline OPH08 & GAAACACCCC & 4 & 1 \\
\hline OPH15 & AATGGCGCAG & 4 & 1 \\
\hline OPH16 & TCTCAGCTGG & 4 & 0 \\
\hline OPH17 & САСТСТССТС & 6 & 4 \\
\hline OPH18 & GAATCGGCCA & 4 & 0 \\
\hline OPI11 & ACATGCCGTG & 5 & 0 \\
\hline OPK04 & CCGCCCAAAC & 5 & 1 \\
\hline OPM04 & GGCGGTTGTC & 6 & 1 \\
\hline OPM06 & CTGGGCAACT & 7 & 4 \\
\hline OPN07 & CAGCCCAGAG & 7 & 1 \\
\hline OPN20 & GGTGCTCCGT & 4 & 0 \\
\hline OPQ10 & TGTGCCCGAA & 7 & 3 \\
\hline OPW16 & CAGCCTACCA & 4 & 1 \\
\hline OPAT04 & TTGCCTCGCC & 5 & 0 \\
\hline OPAT14 & GTGCCGCACT & 2 & 2 \\
\hline
\end{tabular}

*Includes selected polymorphic or monomorphic markers. **Includes only selected polymorphic markers. 
number of selected products generated by each primer varied from two (OPA01, OPG13, OPH04, OPH05, OPAT14) to seven (OPQ10), with DNA bands of 0.2-4.0 $\mathrm{kb}$. The greatest numbers of polymorphic bands (four) were generated by primers OPG14, OPH17 and OPM06 (Table II). Only two accessions (lanes 5 and 7) showed some difference in their DNA bands (Figure 1). Polymorphic amplifications were seen only with accessions 'Sylhat', 'Warnurco', 'Green Rind', 'Tangor' and 'Hung Kait'; the other 14 accessions had identical amplification profiles. Mediterranean mandarin accessions (C. deliciosa Ten.) also have low detectable genetic polymorphism, with most accessions appearing to be clonal (Machado et al., 1996).

A similarity matrix based on the Jaccard coefficient was used to establish the level of relatedness between the 19 accessions studied. The highest estimated genetic similarity coefficient (GS) was 1.0, suggesting that these could have originated from a single clone, or may reflect nondetectable genetic variability. On the other hand, the smallest GS among all accessions was 0.83. Similar results (GS $=0.88$ ) have also been obtained with 39 Mediterranean mandarin (C. deliciosa Ten.) accessions (Machado et al., 1996). An investigation of genetic variability in 35 mandarin accessions, including 10 species and seven hybrids, produced a minimum GS of 0.73 (Coletta Filho et. al., 1998). These high GS values in different mandarin genotypes emphasize the narrow genetic variability within cultivated mandarins.

The dendrogram generated by the UPGMA analysis confirmed the above pattern of diversity (Figure 2). Fourteen accessions (from 'Mandalina' to 'Rosehaugh Nartjee') are probably clones and are known by different local names. Using RAPD markers generated by 23 random primers, Coletta Filho et al. (1998) found no genetic difference among the mandarin accessions 'Ponkan',

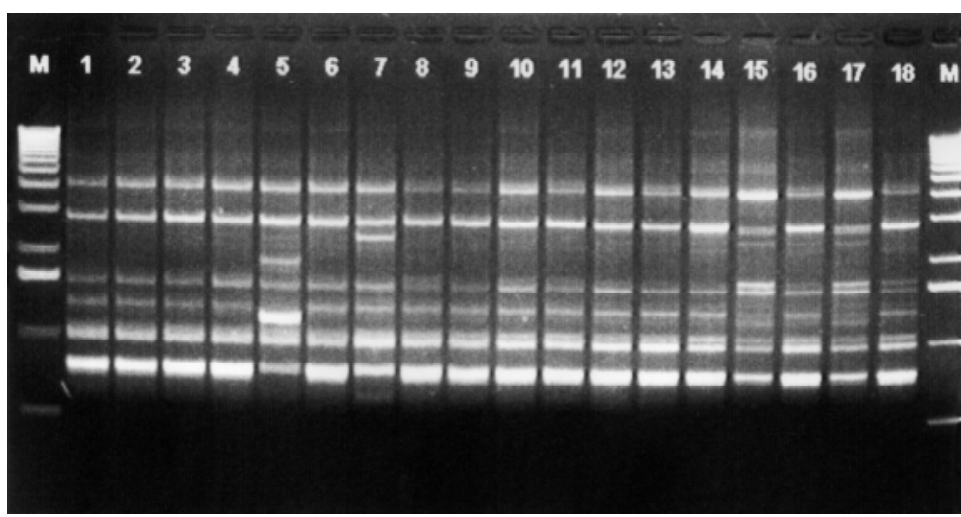

Figure 1 - RAPD amplification products of primer OPQ10 in 18 mandarin accessions. M: Molecular weight markers (1-kb DNA ladder). Lanes 1-18: DNA accessions as listed in Table I.

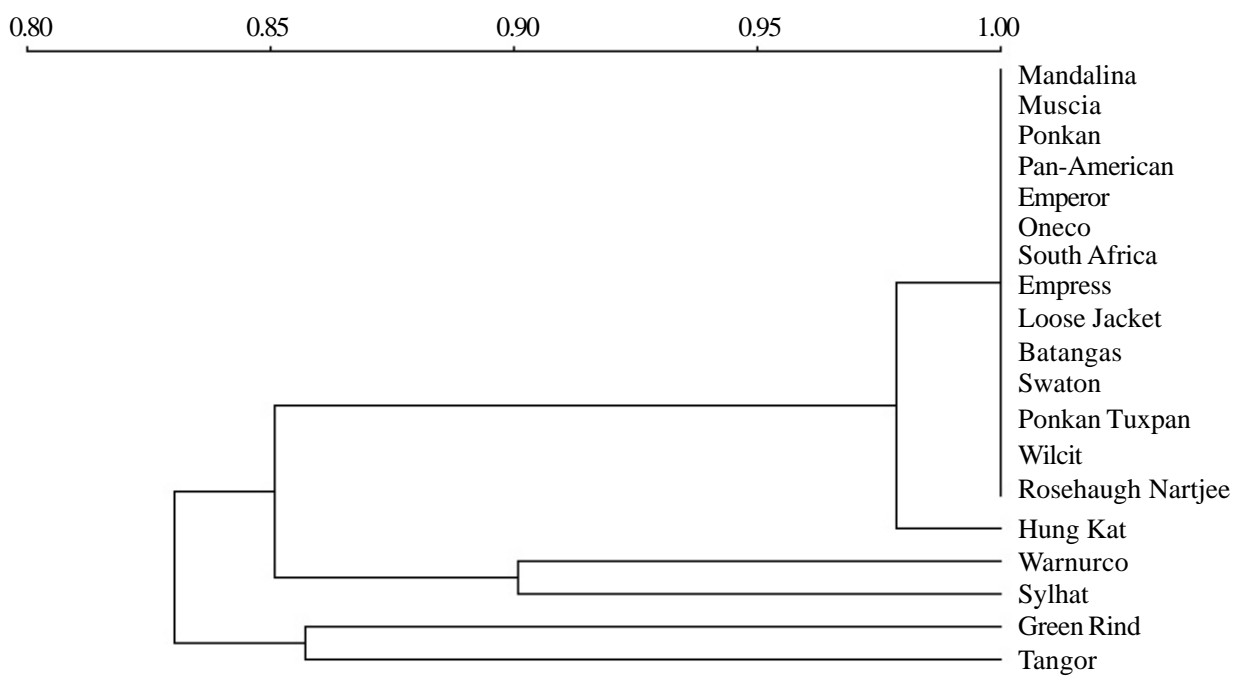

Figure 2 - Dendrogram of 19 accessions of mandarins based on RAPD markers using UPGMA cluster analysis of the Jaccard genetic similarity coefficient. 
'Muscia' and 'Batangas'. These results agree with the observation that Ponkan mandarins spread from Asia to the rest of the world and received different local names. Consequently, 'Emperor' (Australia), 'Empress' (South Africa), 'Oneco' (United States), 'Batangas' (Philippines) and others are probably nucellar clonal budlines of 'Ponkan' mandarin. Similar observations were reported by Hodgson (1967) who noted that 'Ponkan' fruits were sent to the United States in 1893, and seedlings were grown from these and later propagated under the names 'Warnurco' and 'Oneco'. 'Emperor' mandarin originated from seedlings derived from fruits imported from the Orient and is very similar, if not identical, to 'Oneco' and 'Ponkan'. 'Empress' originated either as a mutation or a hybrid derived from South African seedlings believed to be 'Emperor'.

The accession 'Hung Kat' is closely related to the Ponkan clones (Figure 2, GS 0.98). 'Hung Kat', of Chinese origin, probably derived from a mutation or a hybrid with characteristics very similar to 'Ponkan'. The distance between 'Warnurco' and Ponkan clones (GS 0.86) showed that the former was not a 'Ponkan' clone. In addition, the 'Warnurco' used in this research was probably not the same variety described as 'Warnurco' by Hodgson (1967). The most distant accessions were 'Green Rind' and 'Tangor' (GS 0.83), which are probably hybrids derived from the Ponkan mandarin.

Although Ponkan mandarins spread widely from the Orient a long time ago, our results indicate a close genetic relationship among them, perhaps as a result of low mutation and natural hybridization rates. Since five accessions phenotypically similar to Ponkan mandarins were differentiated by RAPD, this procedure represents a powerful tool which can be used to evaluate the genetic diversity of mandarin germplasm collections.

\section{ACKNOWLEDGMENTS}

This work was supported by PADCT/FINEP (Contract No. 64.94.0049.00), RHAE/MCT (Contract No. 610.305/948), and Conselho Nacional de Desenvolvimento Científico e Tecnológico (CNPq). Publication supported by FAPESP.

\section{RESUMO}

Amplificações RAPD foram desenvolvidas utilizando-se 25 "primers" de sequiência aleatória e 19 acessos de tangerinas pertencentes ao grupo das Ponkan. Dos 112 produtos de amplificação selecionados somente 32 foram polimórficos, sendo este polimorfismo restrito somente a 5 acessos. Nos 14 acessos restantes não pôde ser detectada qualquer variabilidade genética, sugerindo que estes podem ser propagação clonal da tangerina
'Ponkan', tendo os mesmos adquirido diferentes nomes regionais ao longo do tempo. Ou, por outro lado, a técnica RAPD utilizada pode não ter detectado qualquer mutação de ponto que tenha ocorrido nestes materiais ao longo do tempo.

\section{REFERENCES}

Albanese, G., Renis, M. and Recupero, G.R. (1992). RFLP analysis of different lemon cultivars. Proc. Int. Soc. Citriculture 1: 208-209.

Bastianel, M., Schwarz, S.F., Coletta Filho, H.D., Lee, L.L., Machado, M.A. and Koller, O.C. (1998). Identification of zygotic and nucellar tangerine seedlings (Citrus spp.) using RAPD. Genet. Mol. Biol. 21: 123-127.

Caetano-Anollés, G., Bassam, B.J. and Gresshof, P.M. (1991). DNA amplification fingerprinting using very short arbitrary oligonucleotide primers. Biotechnology 9: 553-556.

Cai, Q., Guy, C.L. and Moore, G.A. (1994). Extension of the linkage map in Citrus using random amplified polymorphic DNA (RAPD) markers and RFLP mapping of cold-acclimation-responsive loci. Theor. Appl. Genet. 89: 606-614.

Coletta Filho, H.D., Machado, M.A, Targon, M.L.P.N, Moreira M.C.P.Q.D.G. and Pompeu Jr., J. (1998). Analysis of phylogenetic diversity among mandarins (Citrus spp.) using RAPD markers. Euphytica 102: 133-139.

Figueiredo, J.O. (1991). Variedades comerciais. In: Citricultura Brasileira (Rodrigues, O., Viégas, F., Pompeu Jr., J. and Amaro, A.A., eds.). Fundação Cargill, Campinas, pp. 228-264.

Grattapaglia, D. and Sederoff, R. (1994). Genetic linkage maps of Eucalyptus grandis and Eucalyptus urophylla using a pseudo-testcross: mapping strategy and RAPD markers. Genetics 137: 1121-1137.

Herrero, R., Asíns M.J., Pina, J.A., Carbonell, E.A. and Navarro, L. (1996). Genetic diversity in the orange subfamily Aurantioideae. II. Genetic relationships among genera and species. Theor. Appl. Genet. 93: 13271334.

Hodgson, R.W. (1967). Horticultural varieties of citrus. In: The Citrus Industry (Reuthier, W., Webber, H.J. and Batchelor, L.D., eds.). Division of Agriculture Sciences, University of California, Berkeley, pp. 431-591.

Kijas, J.M.H., Fowler, J.C.S. and Thomas, M.R. (1995). An evaluation of sequence tagged microsatellite site markers for genetic analysis within Citrus and related species. Genome 38: 349-355.

Luro, F., Laigret, F., Bove, J.M. and Ollitraut, P. (1992). Application of random amplified polymorphic DNA (RAPD) to Citrus genetics and taxonomy. Proc. Int. Soc. Citriculture 1: 225-228.

Machado, M.A., Coletta Filho, H.D., Targon, M.L.P.N. and Pompeu Jr., J. (1996). Genetic relationship of Mediterranean mandarins (C. deliciosa Tenore) using RAPD markers. Euphytica 92: 321-326.

Motohashi, T., Matsuyama, T. and Akihama, T. (1992). DNA fingerprinting in Citrus cultivars. Proc. Int. Soc. Citriculture 1: 221-224.

Murray, M.G. and Thompson, W.F. (1980). Rapid isolation of high molecular weight plant DNA . Nucleic Acids Res. 8: 4321-4325.

Rohlf, F.J. (1992). NTSYS-PC Numerical Taxonomy and Multivariate Analyses System (Version 1.7). State University of New York, New York, USA.

Sambrook, J., Fritsch, E.F. and Maniatis, T. (1989). Molecular Cloning: a Laboratory Manual. Vol. 1. 2nd edn. Cold Spring Harbor Laboratory Press, New York.

Tanaka, T. (1954). Species Problem in Citrus. Japanese Society for the Promotion of Science, Tokyo.

Young, R.H. (1986). Fresh fruit cultivars. In: Fresh Citrus Fruits (Wardoski, W.F., Nagi, S. and Grierson, W., eds.). Van Nostrand Reinhold Company Inc., New York, pp. 101-126.

(Received September 4, 1998) 